\title{
Analysis of Cracks in an Underground Garage and Research on the Load Test of reinforced pavement
}

\author{
Zhang Zhanhua ${ }^{1, a}$, II jie ${ }^{1, \text { b }}$, Han $\mathrm{Na}^{1, \mathrm{c}}$, liu Kun ${ }^{1, \mathrm{~d}}$, Zhang Shan ${ }^{1, \mathrm{e}}$ \\ ${ }^{1}$ Shandong Quality Inspection and Testing Center of Construction Engineering Co., Ltd, Tianqiao District, Jinan City, Shandong Province, \\ China
}

\begin{abstract}
Cracks often appear in the process of construction and use of concrete structures. It is normal for concrete to have cracks, but the size and quantity of cracks exceed certain limits. Therefore, it is necessary to analyze the structural cracks. According to different cracks, corresponding treatment methods are given. Experiments can be done if conditions permit to verify the safety of the structure after reinforcement. The paper detected and analyzed the cracks appearing on the structure components by using an example of an underground garage project. And It was proposed about corresponding reinforcement treatment scheme. This project provides reference for similar projects or scientific research, and it provides a good research direction.
\end{abstract}

\section{Project Overview}

The main structure of the project is a two-story underground concrete frame structure. The project is about $130 \mathrm{~m}$ long and $20 \mathrm{~m}$ wide. There are design loads of garage as below. The basic snow pressure is $0.2 \mathrm{kN} / \mathrm{m}^{2}$; The basic wind pressure is $0.55 \mathrm{kN} / \mathrm{m}^{2}$; The standard value of dead load of the first underground floor is $40 \mathrm{kN}$ $/ \mathrm{m}^{2}$; The standard value of live load is $15 \mathrm{kN} / \mathrm{m}^{2}$; The standard value of dead load of the second underground floor is $8 \mathrm{kN} / \mathrm{m}^{2}$; The standard value of live load is $5 \mathrm{kN} /$ $\mathrm{m}^{2}$.

\section{Identification and Analysis}

\subsection{Inspection of the Project}

According to Standard for appraisal of reliability of civil buildings $^{[1]}$ (GB 50292-2015)we collected and checked all kinds of construction data. First we check the layout of the building structure. Secondly, the safety of foundation is checked. Finally, the strength, reinforcement and connection of the superstructure are tested. The statistics on the failure forms of various components is as shown in Table 1. Appraisal statistics is shown in Table 1. According to Technical specification for inspection and treatment of cracks in buildings ${ }^{[3]}$ (CECS293-2011), the statistics on the failure forms of various components is as shown in Table 1. Appraisal statistics is shown in Table 1.

Table 1 Failure Category of Components

\begin{tabular}{|c|c|c|c|}
\hline \multicolumn{2}{|c|}{ Testing items } & Engineering Status & $\begin{array}{l}\text { Number of } \\
\text { members }\end{array}$ \\
\hline \multirow{3}{*}{$\begin{array}{l}\text { Frame } \\
\text { Column }\end{array}$} & $\begin{array}{l}\text { First } \\
\text { Kind }\end{array}$ & $\begin{array}{l}\text { The maximum crack width is less than } 0.1 \mathrm{~mm} \text {, and there are } \\
\text { few cracks }\end{array}$ & 10 \\
\hline & $\begin{array}{l}\text { Second } \\
\text { Kind }\end{array}$ & $\begin{array}{l}\text { The maximum width of the crack is less than } 0.3 \mathrm{~mm} \text {, with a } \\
\text { large number and irregular distribution. }\end{array}$ & 18 \\
\hline & $\begin{array}{l}\text { Third } \\
\text { Kind }\end{array}$ & $\begin{array}{l}\text { The maximum width of crack is more than } 0.3 \mathrm{~mm} \text {, the number } \\
\text { is large and the distribution is irregular. }\end{array}$ & 24 \\
\hline $\begin{array}{l}\text { Frame } \\
\text { Beam }\end{array}$ & $\begin{array}{l}\text { First } \\
\text { Kind }\end{array}$ & $\begin{array}{l}\text { The maximum crack width is less than } 0.1 \mathrm{~mm} \text {, and there are } \\
\text { few cracks }\end{array}$ & 24 \\
\hline
\end{tabular}




\begin{tabular}{|c|c|c|c|}
\hline & $\begin{array}{l}\text { Second } \\
\text { Kind }\end{array}$ & $\begin{array}{l}\text { The maximum width of cracks is greater than } 0.2 \mathrm{~mm} \text {, with a } \\
\text { large number of cracks in vertical and oblique directions. }\end{array}$ & 36 \\
\hline \multirow{2}{*}{$\begin{array}{l}\text { Cast-in- } \\
\text { place } \\
\text { slab }\end{array}$} & $\begin{array}{l}\text { First } \\
\text { Kind }\end{array}$ & $\begin{array}{l}\text { The maximum crack width is less than } 0.1 \mathrm{~mm} \text {, and there are } \\
\text { few cracks }\end{array}$ & 10 \\
\hline & $\begin{array}{l}\text { Second } \\
\text { Kind }\end{array}$ & $\begin{array}{l}\text { The maximum crack width is greater than } 0.2 \mathrm{~mm} \text {, and the } \\
\text { direction is inclined to the span direction. }\end{array}$ & 23 \\
\hline
\end{tabular}

\subsection{Analysis of Crack Causes and Reinforcement Methods}

There are many cracks in beams, plates and columns. It does not meet Code for quality acceptance of concrete structures ${ }^{[2]}$ (GB 50292-2015). Reasons are discussed from two aspects: Firstly, the cracks of each component of the project are shrinkage cracks of concrete itself, which are caused by the restraint of concrete shrinkage deformation.; Secondly, There are Improper maintenance during construction. The curing time is shorter and more water is used after concrete pouring.

In Table 1, class II and class III columns are strengthened by increasing section; in Table 1, class II beams and class II slabs are strengthened by pressure grouting and sticking up carbon fiber.

\section{Research on Load Test after Reinforcement}

\subsection{Selection of Experimental Parts and Parameters}

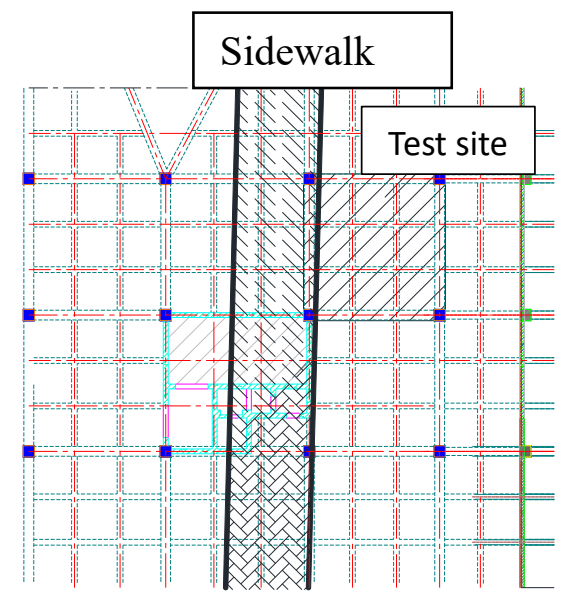

Figure 1 Schematic Diagram of Test Parts

\subsection{Test Process and Precautions}

Each working condition is graded loaded. The loading is increased according to the test vehicle in each lane. The stabilization time of each stage is 5 to 10 minutes. The real-time monitoring readings of the instrument shall prevail, the engine is turned off for 5 to 10 minutes for each loading after the loaded vehicle is loaded in place. The collection after the data is completely stable. In order to restore the elastic deformation of the structure, repeated loading is performed 5-10 minutes after unloading to reduce the influence of plastic residual
Through the static load test, the static effect (static strain, displacement) of the structure under the test load is measured. The standard value of the dead load of the first underground floor is $42 \mathrm{kn} / \mathrm{m}^{2}$, and the standard value of the live load is $15 \mathrm{kn} / \mathrm{m}^{2}$. According to Standard for test method of concrete structures ${ }^{[5]}$ (GB / T 50152-2012), the test load shall be the permanent combination. The test is shown in Figure 1.

\subsection{Test Load and Loading Position}

The dynamic deflection and dynamic coefficient of the structure are measured by dynamic load test. The dump truck is used for loading. The finite element model is established. Three vehicles with a dead weight of 50 tons are used. The model is shown in Figure 2. 9\# measuring points are taken in this inspection, including $8 \#$ strain measuring points and $9 \#$ displacement measuring points. $8 \#$ and 9\# measuring points are respectively on the north and south sides of the column top. The displacement measuring point is to measure the vertical deformation of the beam end.

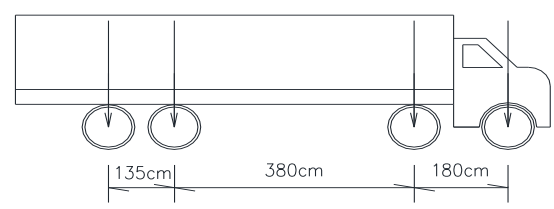

Figure 2 Model Diagram of Loading Vehicle

deformation. Real-time monitoring is also required.

\subsection{Data Analysis of Static Load Test}

(1) Strain data analysis

The measured and calculated values of the tested section strain are shown in Table 2. The strain is positive in tension and negative in compression. 
Table 2 Comparison of Measured and Calculated Strain Values

\begin{tabular}{|c|c|c|c|c|c|c|}
\hline $\begin{array}{c}\text { Measuring } \\
\text { Point }\end{array}$ & $\begin{array}{c}\text { Full load } \\
\text { measured } \\
\text { value }(\mu \varepsilon)\end{array}$ & $\begin{array}{c}\text { Residual } \\
\text { Strain }(\mu \varepsilon)\end{array}$ & $\begin{array}{c}\text { Relative } \\
\text { Residual Strain } \\
(\%)\end{array}$ & $\begin{array}{c}\text { Elastic } \\
\text { Value } \\
(\mu \varepsilon)\end{array}$ & $\begin{array}{c}\text { Calculated } \\
\text { value } \\
(\mu \varepsilon)\end{array}$ & $\begin{array}{c}\text { Check } \\
\text { coefficient }\end{array}$ \\
\hline $1 \#$ & 32.50 & 0.40 & 1.23 & 32.10 & 38.10 & 0.84 \\
\hline $2 \#$ & 41.30 & 0.60 & 1.45 & 40.70 & 44.44 & 0.92 \\
\hline $3 \#$ & 23.70 & 0.40 & 1.69 & 23.30 & 28.57 & 0.82 \\
\hline $4 \#$ & 32.90 & 0.90 & 2.74 & 32.00 & 36.10 & 0.89 \\
\hline $5 \#$ & 41.60 & 0.60 & 1.44 & 41.00 & 47.62 & 0.86 \\
\hline $6 \#$ & 48.90 & 0.40 & 0.82 & 48.50 & 49.30 & 0.98 \\
\hline $8 \#$ & -4.70 & -0.60 & 12.77 & -4.10 & -18.46 & 0.22 \\
\hline $9 \#$ & -8.70 & -0.10 & 1.15 & -8.60 & -15.38 & 0.56 \\
\hline
\end{tabular}

According to table 2, the strain calibration coefficient is between 0.22 and 0.98 , and the relative residual strain is between $0.82 \%$ and $12.77 \%$.

(2) Displacement data analysis
The measured and calculated displace values of the test section are shown in Table 3. The displace is positive upward and negative downward.

Table 3 Comparison of Measured Displacement Data under Full Load

\begin{tabular}{|c|c|c|c|c|c|c|}
\hline $\begin{array}{c}\text { Measuring } \\
\text { Point }\end{array}$ & $\begin{array}{c}\text { Full load } \\
\text { measured } \\
\text { value }(\mu \varepsilon)\end{array}$ & $\begin{array}{c}\text { Residual } \\
\text { Strain } \\
(\mu \varepsilon)\end{array}$ & $\begin{array}{c}\text { Relative } \\
\text { Residual } \\
\text { Strain }(\%)\end{array}$ & $\begin{array}{c}\text { Elastic } \\
\text { Value } \\
(\mu \varepsilon)\end{array}$ & $\begin{array}{c}\text { Calculated } \\
\text { value } \\
(\mu \varepsilon)\end{array}$ & $\begin{array}{c}\text { Check } \\
\text { coefficient }\end{array}$ \\
\hline $1 \#$ & -0.37 & -0.03 & 8.11 & -0.34 & -0.42 & 0.81 \\
\hline $2 \#$ & -0.20 & -0.02 & 10.00 & -0.18 & -0.42 & 0.43 \\
\hline $3 \#$ & -0.22 & -0.03 & 13.64 & -0.19 & -0.36 & 0.53 \\
\hline $4 \#$ & -0.25 & -0.01 & 4.00 & -0.24 & -0.28 & 0.86 \\
\hline $5 \#$ & -0.65 & -0.03 & 4.62 & -0.62 & -0.67 & 0.93 \\
\hline $6 \#$ & -0.64 & -0.08 & 12.50 & -0.56 & -0.69 & 0.81 \\
\hline $7 \#$ & -0.64 & -0.01 & 1.56 & -0.63 & -0.74 & 0.85 \\
\hline $8 \#$ & -0.06 & -0.01 & 16.67 & -0.05 & -0.10 & 0.50 \\
\hline $9 \#$ & -0.08 & -0.01 & 12.50 & -0.07 & -0.08 & 0.88 \\
\hline
\end{tabular}

According to table 3 , the displacement calibration coefficient is between 0.43 and 0.93 , and the relative residual displacement is between $1.56 \%$ and $16.67 \%$. no abnormality occurred to the components during test.

\subsection{Dynamic Load Test}

\subsubsection{Test Point Arrangement and Test Load}

The measuring points of dynamic deflection are arranged at the bottom of the middle span of the secondary beam. The determination of dynamic test load is based on the condition that let the excitation signal to sufficient strength.

\subsubsection{Results and Analysis on Driving Test}

The dynamic deflection time history curve of the structure under moving load is shown in Fig. 3 and Fig. 4.

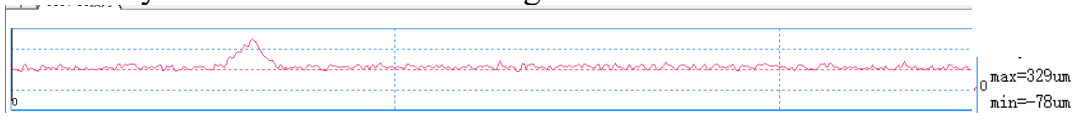

Figure 3 Dynamic Deflection Curve of $30 \mathrm{~km} / \mathrm{h}$ Barrier Free Driving (one ehicle)

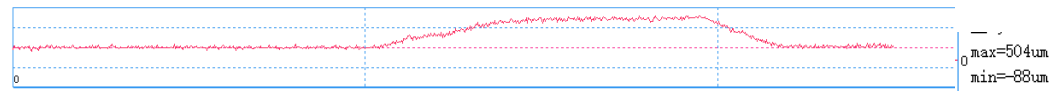

Figure 4 Dynamic Deflection Curve of $30 \mathrm{~km} / \mathrm{h}$ Barrier Free Driving (two ehicles)

According to the barrier free driving test, the dynamic coefficients are 1.10 ( 1 vehicle) and 1.24 ( 2 vehicles). The measured maximum dynamic coefficient is 1.24 which is less than the theoretical calculation value of 1.39. The impact resistance of the structure is better.

\subsubsection{Conclusion}

According to the provisions of the code for Specification for Inspection and Evaluation of Load-bearing Capacity 
of Highway Bridges ${ }^{[4]}(\mathrm{JTG} / \mathrm{TJ} 21-2011)$, the calibration coefficients of the strain and displacement of the tested components are less than 1.00 , so the strength and rigidity of the components meet the design requirements; the relative residual values of the strain and displacement of the tested components are less than $20 \%$, so the tested components are in the elastic working state. Specification for Inspection and Evaluation of Load-bearing Capacity of Highway Bridges ${ }^{[4]}$ (JTG/TJ21-2011).

\section{Summary}

In this paper, the cracks in the concrete components of a garage project are detected and identified, and the causes of cracks are analyzed and discussed. In addition, it is the special situation of the project as under the urban road that a reasonable load test is selected for the top surface of the first underground floor of the project after reinforcement. It was studied and discussed respectively for the static load test and dynamic load test to verify the safety of the structure after reinforcement.

\section{Acknowledgement}

In the process of writing this paper, Hanna put forward valuable opinions and suggestions, and the author would like to express heartfelt thanks. Li Jie actively cooperated in the experiment, and the author would like to express his heartfelt thanks.

\section{References}

1. Standard for appraisal of reliability of civil buildings (GB 50292-2015), Beijing, China Construction Industry Press.

2. Code for quality acceptance of concrete structures construction (GB 50292-2015), Beijing, China Construction Industry Press.

3. Technical specification for inspection and treatment of cracks in buildings(CECS293-2011), Beijing, China Planning Press

4. Specification for Inspection and Evaluation of Load-bearing Capacity of Highway Bridges (JTG/T J 21-2011), Beijing, China Construction Industry Press

5. Standard for test method of concrete structures (GB/T 50152-2012), Beijing, China Construction Industry Press 